\title{
Mathematics Teachers' Attitudes Toward Employing Educational Technologies in Teaching Mathematics at the Negev Schools in Israel
}

\author{
Dr younis hoashla
}

\begin{abstract}
The study aimed to identify mathematics teachers' attitudes toward employing educational technologies at the Negev region schools in teaching mathematics and to identify if there are any statistical differences in mathematics teachers' attitudes toward employing educational technologies at the Negev region schools in teaching mathematics at the level $\alpha \geq 0.05$ based on gender, experience and the educational qualification variables. The sample of the study included 20 teachers ( 10 males $\backslash 10$ females ) whom were randomly selected. To achieve the goals of the study, the researcher developed the 30-items " Mathematics teachers' attitudes toward employing technology in teaching mathematics' questionnaire. Result indicated that there is a negative attitude towards Employing Educational Technologies in Teaching Mathematics and also indicated statistical differences in averages based on gender and these differences were in favor of female teachers, and differences that are attributed to experience in favor of experience of $(5-10$ Years). and differences that are attributed to the educational qualification in favor of higher studies certificates. In light of the results the researcher concluded with recommendations for future research and those concerned in teaching methods.
\end{abstract}

Keywords: Mathematics' Teachers / Attitudes / Educational Technologies/ Negev Schools in Israel

DOI: $10.7176 / \mathrm{JEP} / 10-2-11$

\section{Introduction :}

Many students amply that they don't like mathematics because it is difficult to understand, mathematics actually is among the very important sciences, it is the language of the modern age, the language of accuracy and without mathematics there would be no development at all levels and there would be no modern techniques . Mathematics is the measurement of development and civilizations so there must be a focus on how it is offered to students and educators should employ all possible techniques and methods in order to make it favorable and accepted by students at all educational stages.

In the past decade, there was a great revolution in technology where technology has been utilized in all life aspects and all sectors all over the world and this has greatly affected human life, and in this regard, Elrawabda, (2002 ) states that people experience a great set of changes as a result of the scientific and technological revolution .

Alghamdi (2017) indicates that there is a focus on utilizing information technologies in education including Mathematics teaching and this represents the main interest of many nations because of their effective role in the development and progress of societies. And in this regard, (Elzahrany, 2005) states that Math teachers should to promote its level of teaching and achieve the desired outcomes which requires cooperative efforts and exploiting capabilities and abilities and this would not be achieved unless teaching methods are developed.

For the significance of education as whole and mathematics teaching in particular in nations' life, and for the great significance of technology in today's teaching, it is necessary for those responsible for education to pay much interest and make much efforts regarding the development of the educational process to achieve its desired goals benefiting from the great advantages offered to the educational process by technology. Ron ( 2009 ) indicates that the flexible nature of technology forced teachers to re-assess the mathematics that students need to determine the best methods for attaining higher levels of mathematics achievement. Many students are struggling to learn mathematics today.

\section{Statement of the Problem and Study Questions :}

The researcher. As a mathematics teacher THE Negev region in Israel, has noticed a difficulty related to teaching mathematics and low achievement levels in mathematics among students which attributed to the lack for using the best educational and teaching methods by mathematics teachers in teaching mathematics. In addition, most students find it difficult to learn mathematics so teachers should utilize new and beneficial teaching methods to make this material acceptable by students. This study came to investigate Mathematics Teachers' Attitudes Toward Employing Educational Technologies in Teaching Mathematics at the Negev Schools in Israel and to answer the following research questions :

1- How do mathematics teachers in the Negev region schools view the use of educational technologies in teaching mathematics?

2- Are there statistical significant differences at the level $\alpha \geq 0.05$ in mathematics teachers Negev region schools 
attitudes toward employing educational technologies in teaching mathematics that are attributed to the gender ( male $\backslash$ female ), Experience ( less than 5 years, 5-10 years, more than 10 years ) and educational qualification ( Diploma, Bachelor, MA, PhD ) variables?

\section{Study Goals :}

The study aimed to identify mathematics teachers' attitudes toward employing educational technologies at the Negev region schools in teaching mathematics and to identify if there are any statistical differences in mathematics teachers' attitudes toward employing educational technologies at the Negev region schools in teaching mathematics at the level $\alpha \geq 0.05$ based on the gender, experience and the educational qualification variables.

\section{Significance of the Study :}

The significance of the study comes from the significance of the topic it addresses " mathematics teachers' attitudes toward employing educational technologies at the Negev region schools in teaching mathematics " and also lies in that it will contribute assisting mathematics teachers to apply and implement educational technologies in their mathematics classes in addition to benefiting mathematics curriculum planners to adopt educational technologies main references in lessons and finally, the significance of this study lies in that it is among the first to address this topic in the Negev region.

\section{Procedural Definition :}

Mathematics teachers : All male and female mathematics teachers teaching mathematics in Negev public schools in the first semester of the academic year $2018 \backslash 2019$.

Attitudes : Allport ( stated in Siddiq, 2012 ) defines attitudes as mental states of preparation and readiness organized by experience and directs individuals' responses toward the various things and situations. While Weiner et al ( 2010 ) defines attitudes as the emotional state based on an individual's point of view or belief toward a specific topic to accept or reject it .

In this study, attitudes are the scores obtained by mathematics teachers in the Negev region on the Mathematics teachers' attitudes toward employing educational technologies in teaching mathematics' scale developed for the purposes of this study.

Technology : Deliow ( 2010 ) indicates that the term technology was first used in Germany in 1770 and originally it is composed of two parts : Techno which means art or a craft and Logie which means science or theory and defined in the American Heritage Dictionary, 2009 as referring to applications, methods, theories, and practices that are used to reach desirable ends, especially industrial and commercial ends .

Educational Technology : defined by Januszewski \& Molenda (2008) as the study and ethical practice of facilitating learning and improving performance by creating, using, and managing appropriate technological processes and resources. Zaitoun ( 2006 ) defines it as offering an educational content vie the multiple technological and computer - based methods and programs in a pattern that allows interaction with this content , teacher, and learner.

In this study, educational technologies are organized educational processes consisted of teaching methods, educational methods and educational assessment utilized for mathematics in Negev region schools.

\section{Literature Review}

Mathematics is a form of reasoning. Thinking mathematically consists of thinking in a logical manner, formulating and testing conjectures, making sense of things, and forming and justifying judgments, inferences, and conclusions .

The main goal of mathematics education in schools is the mathematisation of the child's thinking. Clarity of thought and pursuing assumptions to logical conclusions is central to the mathematical enterprise. There are many ways of thinking, and the kind of thinking one learns in mathematics is an ability to handle abstractions, and an approach to problem solving. Universalisation of schooling has important implications for mathematics curriculum. Mathematics being a compulsory subject of study, access to quality mathematics education is every child's right. We want mathematics education that is affordable to every child, and at the same time, enjoyable ( National Council for Educational Research and Training, 2006 ) .

Terry (2000) indicated several things to be investigated in mathematics education and stated that it is easy to be overwhelmed, these include : The students trying to learn mathematics, The teachers trying to teach mathematics, The content of mathematics and its organization into a curriculum and The pedagogical models for presenting and experiencing this mathematical content .

In relation to mathematics teaching, educational technologies are among the new attitudes in the educational system and is the most prominent term within the educational environments and should be emphasized by mathematics teachers in order to increase students achievement and facilitate the teaching of 
mathematics. Educational technologies based learning is divided into two main types as indicated by Mursi ( 2005 ) : Synchronous E-learning which depends on the internet to communicate and exchange information and lessons and needs the existence of the teacher and the learner at the same place for achieving the process of teaching such as (immediate conversation and receiving lessons virtually via the internet and satellites and other methods, the other type is A Synchronous E-learning within which a learner receives costly lessons based on planned educational program where time and places are selected by employing some electronic education methods.

The various activities included in information and communication technologies should be an integral part of mathematics' teaching and learning, and mathematics teacher should organize, control and follow it up which requires him \her to develop and increase the necessary skills (Ostah, 2005 ) so , educational facilities and those interested in mathematics' teaching and learning should pay a great attention to mathematics teachers' attitudes toward educational technologies and employing them in mathematics' teaching and learning if we want to achieve the desired goals of teaching mathematics.

\section{Early Studies :}

RAMADAN and HÜSEYIN ( 2014 ) students' attitudes towards technology use in class and whether the use of technology improved their academic achievement. A quasi-experimental research design was used and they assigned 3 groups as experimental groups $(n=41)$ and 2 as control groups $(n=41)$. Mathematics was selected as the subject to be studied. All groups completed a pretest and a posttest. For the experimental groups, lessons were designed using several technological tools, whereas lessons for control groups were taught using traditional teaching methods. At the end of the study, the experimental groups completed a scale to investigate the preferences and attitudes of the students in regard to technology-based instruction. One-way ANCOVA was used to evaluate the differences in posttest results, which revealed that the mathematics posttest results of the students who were instructed using technology were significantly higher than the posttest results of the groups who were instructed without technology. Results showed that students had a positive attitude towards technology use.

Dorian ( 2009 ) conducted a study to document and analyze teachers' choices in educational technology use with regards to promotion of social activism; explore existent pedagogical development ideas and pedagogical activism in mathematics education and to propose a research methodology that explores mathematics teachers' challenges in using educational technology. Three high school mathematics teachers from Greater Toronto Area are selected to participate in this research. Actor Network Theory (ANT) was considered as research paradigm for this study. Results indicated that teachers who had a "traditional perspective" of teaching mathematics and the overall finding indicated that teachers ability to provide a successful interplay between using technology and including social issues in teaching mathematics is quite challenging.

Moila ( 2006 ) investigated the use of educational technology in Mathematics teaching and learning. In order to achieve this goal, Phusela Secondary school was visited for the whole week to conduct the study.It was found that there are no plans on the use of educational technology tools in Mathematics teaching and learning, inadequate educators' training on the use of educational technologies in teaching and learning and there was lack of relevant educational technology tools for rural schools.

Hamadnih and Alshawaheen ( 2016 ) investigated mathematics teachers' attitudes toward using the social media ( face book )in teaching mathematics in Jordan. Their sample included (80) male and female teachers. Results indicated high positive attitudes toward using social media in teaching mathematics among Jordanian mathematics' teachers with no statistical differences based on the variable of gender.

Qarawani's study ( 2010 ) aimed at investigating and analyzing the attitudes of mathematics and computer students at Alquds Open University in Salfeet educational region towards e-learning application in mathematics, the study also aimed to know whether the study variables have an effect upon the attitudes of mathematics and computer students towards the application of e-learning. The questionnaire was consisting of (33) items, and after making sure that it was reliable and stable, it was distributed to a sample of (50) male and female who were studying at mathematics and computer departments in the first semester 2009/2010. The results revealed that the attitudes of students were weak, besides this it showed that the attitudes of mathematics students are more positive than computer students, while there were no statistically significant differences in the attitudes of students due to the gender and the accumulated average variables.

\section{Methodology :}

The study followed the descriptive survey approach as it is appropriate for describing and determining the facts related to the status and the topic this study addressed.

\section{Population and sample :}

The population of the study was the whole male and female Mathematics' teachers at the Negev region schools from which 20 teachers ( 10 males $\backslash 10$ females ) were randomly selected as the sample of the study. Table (1) 
shows the frequencies and percentages of the study sample based on gender, educational level and experience variables.

\begin{tabular}{|c|c|c|c|}
\hline Variables & Variable Levels & Frequency & Percentage \\
\hline \multirow{2}{*}{ Gender } & Male & 19 & $48 \%$ \\
\hline & Female & 21 & $53 \%$ \\
\hline \multirow{4}{*}{$\begin{array}{l}\text { Educational } \\
\text { Qualification }\end{array}$} & Diploma & 12 & $30 \%$ \\
\hline & Bachelor & 16 & $40 \%$ \\
\hline & Master & 12 & $30 \%$ \\
\hline & PhD & 12 & $30 \%$ \\
\hline \multirow{3}{*}{ Experience } & Less than 5 years & 10 & $25 \%$ \\
\hline & 5-10 years & 10 & $25 \%$ \\
\hline & $\begin{array}{c}\text { More than } 10 \\
\text { years }\end{array}$ & 8 & $20 \%$ \\
\hline \multicolumn{2}{|c|}{ Total } & 40 & $100 \%$ \\
\hline
\end{tabular}

\section{Study Tool :}

For the purpose of this study and after reviewing the educational literature and studies related to the topic of this study, The researcher developed the 30-items " Mathematics teachers' attitudes toward employing technology in teaching mathematics " questionnaire.

\section{The Content Validity of the tool :}

To check for validity of the tool, it was submitted to a jury of to 10 faculty members to judge the validity of the items, or if there is a need for any modification or deletion. They gave their opinions and based on their opinions items that gained $80 \%$ or above of agreement were selected for the questionnaires. The researcher modified some items based on their opinions and in its final version, the tool was consisted of 30 items.

\section{The Reliability of the tool :}

To check for the reliability of the tool, it was applied on a pilot sample consisted of (30) male and female mathematics teachers form the population of the study and outside of the original sample, and after two weeks the questionnaires were applied again on the same sample, the Pearson Correlation Coefficient was calculated and was (0.81) and Cronbach Alpha was calculated, and was (0.89).

\section{Procedures :}

To achieve the goals of the study, and to answer its questions, the researcher followed the following procedures :

- Reviewing a group of early related studies and educational literature related to the topic of the study .

- Developing the tool of the study and checking its reliability and validity.

- Selecting the population and the sample of the study .

- Applying the tool on a pilot sample.

- Distributing the tool on participants .

- Collecting the questionnaires and using the SPSS software for the appropriate statistical analysis .

- Offering the results of the study and suggesting recommendations based on these results.

\section{Study Variables :}

The study included the following independent variables :

* Gender ( malelfemale)

* Educational; Qualification (Diploma, Bachelor, Master, PhD )

* Experience (Less than 5 years, 5-10 years, More than 10 years )

And one dependent variable:

* Mathematics Teachers' Attitudes Toward Employing Technology in Teaching Mathematics.

\section{Results:}

To achieve the first aim of the study, Means, Standard deviations and Ranks for all participants according to their Answers on study tool were calculated, Table (2) shows the Means, Standard deviations and Ranks for all participants according to their responses on study tool . 
Table (2)

Means and the standard deviations for responses on the study tool

\begin{tabular}{|c|c|c|c|c|c|}
\hline No. & Statement & Mean & S.D & $\begin{array}{c}\text { Level of } \\
\text { agreement }\end{array}$ & Rank \\
\hline 1 & Using technologies is very important in education & 3.43 & 0.87 & Moderate & 12 \\
\hline 2 & $\begin{array}{l}\text { I agree with designing Arabic sites for teaching Mathematics on } \\
\text { the Internet }\end{array}$ & 3.25 & 0.98 & Moderate & 20 \\
\hline 3 & $\begin{array}{l}\text { I think that technology is effective in mathematics teaching } \\
\text { learning process }\end{array}$ & 3.55 & 1.01 & Moderate & 5 \\
\hline 4 & Technology is important for both teacher and student & 3.18 & 1.13 & Moderate & 27 \\
\hline 5 & Technology enriches mathematics teaching & 3.68 & 0.97 & High & 1 \\
\hline 6 & Using technology in mathematics teaching is a waste of time & 3.2 & 0.82 & Moderate & 24 \\
\hline 7 & $\begin{array}{l}\text { Technology increased information communication and exchange } \\
\text { in the educational environment }\end{array}$ & 3.48 & 0.93 & Moderate & 10 \\
\hline 8 & Technology offers teachers better educational experiences & 3.58 & 0.84 & Moderate & 4 \\
\hline 9 & $\begin{array}{l}\text { Technology has changed the teacher's role to be instructor and } \\
\text { facilitator }\end{array}$ & 3.25 & 0.87 & Moderate & 21 \\
\hline 10 & $\begin{array}{l}\text { I have the desire to acquire all technology-related skills to } \\
\text { utilize it in teaching }\end{array}$ & 3.38 & 0.84 & Moderate & 16 \\
\hline 11 & Technology develops a self-learning skill & 3.43 & 1.01 & Moderate & 13 \\
\hline 12 & $\begin{array}{l}\text { I feel comfort when deal with educational technological staff } \\
\text { and materials }\end{array}$ & 3.2 & 0.91 & Moderate & 25 \\
\hline 13 & $\begin{array}{l}\text { Technology achieves a positive interaction among the } \\
\text { components of the educational process }\end{array}$ & 3.48 & 0.88 & Moderate & 11 \\
\hline 14 & I heavily depend on technology in teaching mathematics & 3.35 & 0.86 & Moderate & 18 \\
\hline 15 & $\begin{array}{l}\text { I encourage all mathematics teachers to utilize technology in } \\
\text { teaching }\end{array}$ & 3.53 & 0.82 & Moderate & 7 \\
\hline 16 & $\begin{array}{l}\text { Technology has increased and developed new social } \\
\text { relationships with other parties than the educational environment }\end{array}$ & 3.5 & 0.99 & Moderate & 8 \\
\hline 17 & $\begin{array}{l}\text { I use technological methods to assess students and offer their } \\
\text { results }\end{array}$ & 3.38 & 0.81 & Moderate & 17 \\
\hline 18 & I encourage adopting technology for school tests & 3.2 & 1.16 & Moderate & 26 \\
\hline 19 & $\begin{array}{l}\text { I feel that I am a positive member when utilizing technology for } \\
\text { teaching }\end{array}$ & 3.13 & 1.02 & Moderate & 29 \\
\hline 20 & I wish to participate in more technology-related training courses & 3.43 & 1.01 & Moderate & 14 \\
\hline 21 & I always review the latest advances in educational technologies & 3.08 & 1.07 & Moderate & 30 \\
\hline 22 & Technology encourage the daily follow up for students & 3.55 & 0.88 & Moderate & 6 \\
\hline 23 & Technology greatly support the school curriculum & 3.35 & 1 & Moderate & 19 \\
\hline 24 & $\begin{array}{l}\text { Students become more interactive when use technological } \\
\text { methods }\end{array}$ & 3.68 & 0.94 & High & 2 \\
\hline 25 & $\begin{array}{l}\text { Online educational technologies allow me to keep in touch with } \\
\text { mathematics teachers other than those within my educational } \\
\text { environment }\end{array}$ & 3.18 & 0.84 & Moderate & 28 \\
\hline 26 & It is interesting when use educational technologies & 3.63 & 1.03 & Moderate & 3 \\
\hline 27 & $\begin{array}{l}\text { I receive appropriate support from the school regarding using } \\
\text { the educational technologies }\end{array}$ & 3.43 & 0.98 & Moderate & 15 \\
\hline 28 & $\begin{array}{l}\text { I trust the information students obtain using online educational } \\
\text { technologies }\end{array}$ & 3.25 & 1.06 & Moderate & 22 \\
\hline 29 & $\begin{array}{l}\text { I think that there is a lack for research regarding developing } \\
\text { educational technologies in the Negev region }\end{array}$ & 3.23 & 1.00 & Moderate & 23 \\
\hline 30 & $\begin{array}{l}\text { The school follow up students' use for online resources and } \\
\text { blocks undesired sites and content. }\end{array}$ & 3.5 & 1.04 & Moderate & 9 \\
\hline \multicolumn{2}{|r|}{ Total Indicator } & 3.38 & 0.45 & & \\
\hline
\end{tabular}

Table (2) presents the statistical analysis for all participants according to their responses on the items of the study tool which scored a total mean of (3.38) with a standard deviation of $(0.45)$. This indicates that there is a negative attitude towards Employing Educational Technologies in Teaching Mathematics because its mean is equal to the mean of (3.67). 
To achieve the second aim, the One Way ANOVA test was used for the overall means of study tool, Table (3) shows the means and standard deviations for participants based on the variables of gender, Experience and educational qualification.

Table (3)

means and standard deviations among study sample according gender, Experience and educational qualification.

\begin{tabular}{|c|c|c|c|c|}
\hline Variable & Group & Mean & S.D & No. \\
\hline \multirow{2}{*}{ Gender } & Male & 3.06 & 0.33 & 19 \\
\cline { 2 - 5 } & Female & 3.67 & 0.35 & 12 \\
\hline \multirow{2}{*}{ Experience } & Less than 5 & 3.14 & 0.32 & 16 \\
\cline { 2 - 5 } & $5-10$ years & 3.64 & 0.39 & 12 \\
\cline { 2 - 5 } & More than 10 & 3.36 & 0.50 & 12 \\
\hline \multirow{2}{*}{$\begin{array}{c}\text { educational } \\
\text { qualification }\end{array}$} & Diploma & 2.95 & 0.22 & 10 \\
\cline { 2 - 5 } & Bachelor & 3.26 & 0.43 & 8 \\
\cline { 2 - 5 } & Master & 3.70 & 0.29 & 40 \\
\hline
\end{tabular}

Table (3 ) indicates statistical significant differences in means based on gender, experience and scientific qualification, Accordingly, One Way ANOVA test was conducted to determine in favor of whom and which these differences were as shown in the table (4).

Table (4)

One Way ANOVA test results based on gender, Experience and educational qualification variables

\begin{tabular}{|c|c|c|c|c|c|c|}
\hline Variable & Source & Sum of Squares & df & Mean Square & F & Sig. \\
\hline \multirow{5}{*}{ Gender } & Between Groups & 3.712 & 1 & 3.712 & 32.386 & 0.00 \\
\cline { 2 - 7 } & Within Groups & 4.356 & 38 & .115 & & \\
\cline { 2 - 7 } & Total & 8.068 & 39 & & & \\
\hline \multirow{5}{*}{ Experience } & Between Groups & 1.501 & 2 & .751 & 4.229 & 0.02 \\
\cline { 2 - 7 } & Within Groups & 6.567 & 37 & .177 & & \\
\cline { 2 - 8 } & Total & 8.068 & 39 & & & \\
\hline educational qualification & Between Groups & 4.728 & 3 & 1.576 & 16.989 & 0.00 \\
\cline { 2 - 8 } & Within Groups & 3.340 & 36 & .093 & & \\
\cline { 2 - 8 } & Total & 8.068 & 39 & & & \\
\hline
\end{tabular}

The results of Table ( 4) indicate that there are statistical differences in attitude towards Employing Educational Technologies in Teaching Mathematics according to the variable gender in favor of female teachers with a mean of (3.67) compared to males whose mean was (3.06). To identify the differences according to the Experience and the educational qualification variables, the Scheffe's test was conducted as shown in the table (5) below.

Table (5)

The Scheffe's test results to estimate the effect of Experience and educational qualification variables on attitudes toward Employing Educational Technologies in Teaching Mathematics.

\begin{tabular}{|c|c|c|c|c|c|}
\hline Variable & Group & Other groups & Mean Difference (I-J) & Std. Error & Sig. \\
\hline \multirow{3}{*}{ Experience } & \multirow{2}{*}{ Less than 5} & $5-10$ & 0.2152 & 0.1609 & 0.42 \\
\hline & & More than 10 & 0.4983 & 0.1720 & 0.02 \\
\hline & $5-10$ & More than 10 & 0.2831 & 0.1609 & 0.23 \\
\hline \multirow{6}{*}{ educational qualification } & \multirow[t]{3}{*}{ Diploma } & Bachelor & 0.3150 & 0.1304 & 0.14 \\
\hline & & Master & 0.7540 & 0.1304 & 0.00 \\
\hline & & $\mathrm{PhD}$ & 0.8375 & 0.1390 & 0.00 \\
\hline & \multirow[t]{2}{*}{ Bachelor } & Master & 0.4390 & 0.1362 & 0.03 \\
\hline & & $\mathrm{PhD}$ & 0.5225 & 0.1445 & 0.01 \\
\hline & Master & $\mathrm{PhD}$ & 0.0835 & 0.1445 & 0.95 \\
\hline
\end{tabular}

The results of Table (5) indicate the followings:

- There were differences between teachers with an experiences of (5-10 Years) and those with experiences of (less than 5 Years) in favor of teachers with (5-10 Years) experiences.

- There were differences between all categories of teachers according to the educational qualification, the higher educational qualification $\mathrm{s}$ had the most positive attitudes. 
Discussion:

The results of the study indicated the following:

- The attitudes towards Employing Educational Technologies in Teaching Mathematics

- There are statistical differences in attitude towards Employing Educational Technologies in Teaching Mathematics according to gender in favor of female (3.67) As compared to males.

- There are differences between experienced teachers (5-10 Years) and experienced teachers (less than 5 Years) in favor of experienced teachers $(5-10$ Years).

- There are differences between all categories of teachers according to the scientific qualification, the higher scientific qualification is the more positive trends

References

Alghamdi, Mona ( 2017 ) The Reality and Difficulties of Employing ICT in Teaching from the Perspective of Math Teachers of Middle Stage in Riyadh. International Education Studies; Vol. 10, No. 12; 2017ISSN 1913-9020 E-ISSN 1913-9039 Published by Canadian Center of Science and Education.

Deliow, Fadheel (2010) The New Media and Communication Technology : Concept, Uses and Horizons. Dar Al-Thaqafah, Jordan, Amman .

Dorian Stoilescu ( 2009 ) IS EDUCATIONAL TECHNOLOGY USEFUL TO MATHEMATICS TEACHERS ACTIVISTS? Acta Didactica Napocensia. Volume 2.

Elrawabda, M. A. (2002). The impact of using the educational packages in teaching the recitation of the Holy Qur'an (Unpublished MA. thesis). Al Albayt University.

Elzahrany, A.A. (2005). The reality of using the computer and Internet in teaching Mathematics to the secondary stage from the perspective of teachers and educational supervisors (Unpublished MA. thesis). Umm Al-Qura University.

Januszewski, A., \& Molenda, M. (2008). Educational technology: A definition with commentary . New York, NY: Lawrence Erlbaum Associates.

Hamadnih, Mou'nis and Alshawaheen, Suzan ( 2016 ) Mathematics Male and Female Teachers Attitudes Toward Using the Social Media ( Face Book ) in Teaching Mathematics. Ministry of Education In Jordan. Alquds Open University Journal for Educational and Psychological Research and Studies.Vol (5), Ed (18).

Moila, MM ( 2006 )The Use of Educational Technology in Mathematics Teaching and Learning: An Investigation of a South African Rural Secondary School. Mini-dissertation in partial fulfillment of the requirements for M.Ed. (CIE), University of Pretoria.

Qarwani, Mahir ( 2010 ) Attitudes of Mathematics and Computer Students' towards e-learning application in mathematics at Alquds Open University in Salfeet educational region. Mathematics teaching methods' coordinator at Alquds Open University.

Ramadan ,Eyyam and Huseyi'n, s ( 2014 ) IMPACT OF USE OF TECHNOLOGY IN MATHEMATICS LESSONS ON STUDENT ACHIEVEMENT AND ATTITUDES. SOCIAL BEHAVIOR AND PERSONALITY. Society for Personality Research .Eastern Mediterranean University

Ron Y. Myers ( 2009 ) The Effects of the Use of Technology In Mathematics Instruction on Student Achievement . Florida International University, Electronic Theses and Dissertations University Graduate School.

Siddiq, Hassan ( 2012 ) Attitudes from Sociology. Damascus University Journal, Vol 28, Eds 3+4. Faculty of Arts and Human Sciences. Damascus University.

Technology. (2009). In The American Heritage Dictionary of the English Language. Retrieved from http://thefreedictionary.com/technology.

Terry Bergeson, Rosemary Fitton, and Pete Bylsma ( 2000 ) Teaching and Learning Mathematics Using Research to Shift From the "Yesterday" Mind to the "Tomorrow" Mind, The Office of Superintendent of Public Instruction.

Weiner, Bernard, Danny Osborne, and Udo Rudolph. ( 2010 ) "An Attributional Analysis of Reactions to Poverty: The Political Ideology of the Giver and the Perceived Morality of the Receiver." Personality and Social Psychology Review : 1- 15.

Zaitoun, Hassan ( 2006 ) Electronic Education : Concept, Issues, Application and Evaluation. Addar Alsoltieah for publication. Riyadh, KSA. 


\section{Appendix (A)}

Study Tool

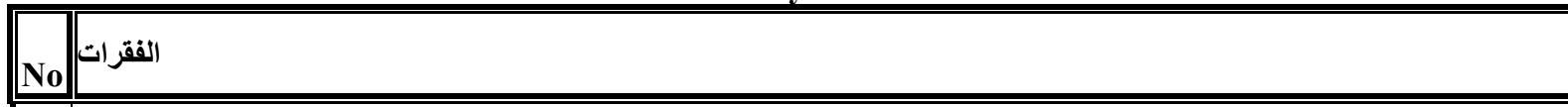

1 Using technologies is very important in education

2 I agree with designing Arabic sites for teaching Mathematics on the Internet

3 I think that technology is effective in mathematics teaching learning process

3 Technology is important for both teacher and student

5 Technology enriches mathematics teaching

6 Using technology in mathematics teaching is a waste of time

7 Technology increased information communication and exchange in the educational environment

8 Technology offers teachers better educational experiences

9 Technology has changed the teacher's role to be instructor and facilitator

10 I have the desire to acquire all technology-related skills to utilize it in teaching

10 Technology develops a self-learning skill

12 I feel comfort when deal with educational technological staff and materials

13 Technology achieves a positive interaction among the components of the educational process

13 I heavily depend on technology in teaching mathematics

15 I encourage all mathematics teachers to utilize technology in teaching

16 Technology has increased and developed new social relationships with other parties than the educational environment

17 I use technological methods to assess students and offer their results

18 I encourage adopting technology for school tests

19 I feel that I am a positive member when utilizing technology for teaching

20 I wish to participate in more technology-related training courses

21 I always review the latest advances in educational technologies

21 Technology encourage the daily follow up for students

23 Technology greatly support the school curriculum

24 Students become more interactive when use technological methods

25 Online educational technologies allow me to keep in touch with mathematics teachers other than those

25 within my educational environment

26 It is interesting when use educational technologies

27 I receive appropriate support from the school regarding using the educational technologies

28 I trust the information students obtain using online educational technologies

29 I think that there is a lack for research regarding developing educational technologies in the Negev region

30 The school follow up students' use for online resources and blocks undesired sites and content. 